\title{
EFFECT OF WALKING EPIDURAL DOSE ON LABOUR DURATION AND ANALGESIA
}

\author{
Srilakshmi Kothakoona ${ }^{1}$, T. Suryasree2, P. Tanuja Rajyalakshmi Devi ${ }^{3}$
}

${ }^{1}$ Associate Professor, Department of Anaesthesiology, Siddhartha Medical College, Vijayawada, Andhra Pradesh.

2 Professor and HOD, Department of Anaesthesiology, Siddhartha Medical College, Vijayawada, Andhra Pradesh.

${ }^{3}$ Assistant Professor, Department of Anaesthesiology, Siddhartha Medical College, Vijayawada, Andhra Pradesh.

\section{ABSTRACT}

Walking or ambulation ${ }^{1}$ during normal delivery (labour) is a popular choice for labour analgesia in recent trends, which allows the labouring mother to enjoy the childbirth with active and cheerful participation without any pain.

\section{AIM}

To study the effect of Walking Epidural dose 2,3 on Labour duration and Analgesia.

\section{MATERIALS AND METHODS}

In this Prospective Outcome Study, 30 Nulliparous women were given Epidural Analgesia with Ropivacaine and Fentanyl during Labour pain and studied the duration of Labour, Analgesia, and effects on Mother and Foetus. ${ }^{4}$

\section{RESULTS}

In the present study with a Walking Epidural analgesia dose of $15 \mathrm{~mL}$ of $0.125 \%$ Ropivacaine 5 and Fentanyl $2 \mu \mathrm{g} / \mathrm{mL}$. The onset of analgesia was 10 minutes and lasted for 3 hours 30 minutes. There is no effect on the duration of $1^{\text {st }}$ stage of Labour. APGAR score at 1 minute was 8 in 94\% cases and APGAR at 5 minutes was 10 in $94 \%$ of cases.

\section{CONCLUSION}

The parturient participated actively in the process of childbirth without delay in the first stage of labour. Neither significant haemodynamic changes nor adverse effects were observed in both newborn and mother.

\section{KEYWORDS}

Obstetrical Analgesia, Fentanyl, Ropivacaine, Apgar Score, Labour Stage First.

HOW TO CITE THIS ARTICLE: Kothakoona S, Suryasree T, Devi PTR. Effect of walking epidural dose on labour duration and analgesia. J. Evolution Med. Dent. Sci. 2016;5(69):4972-4975, DOI: 10.14260/jemds/2016/1129 \section{INTRODUCTION \\ Walking 6 or ambulation during normal delivery (Labour) is a} popular choice for labour analgesia in recent trends, which allows the labouring mother to enjoy the childbirth with active and cheerful participation without any pain. During labour by nature, mother experiences severe pain and gives birth to the child. With the use of epidural analgesia from $19^{\text {th }}$ century labour pain became painless. Pain relief in labour has always been with myths and controversies, hence providing effective and safe analgesia during labour is an ongoing challenge. The pioneers of epidural analgesia are Tuffier and Sicard in 1921 and epidural catheter technique was introduced by Tuohy.

\section{AIM}

To study the effect of Walking Epidural dose on Labour duration and Analgesia.

\section{MATERIALS, METHODS, AND PROCEDURE}

The Study was approved by Institutional Ethical Committee of Siddhartha Medical College, Vijayawada, Andhra Pradesh.

Financial or Other, Competing Interest: None.

Submission 20-07-2016, Peer Review 13-08-2016,

Acceptance 19-08-2016, Published 27-08-2016.

Corresponding Author:

Dr. Srilakshmi Kothakoona,

\#39-8-39,

Muralinagar,

Visakhapatnam-530007,

Andhra Pradesh

E-mail:dr.ksl.md@gmail.com

DOI: $10.14260 /$ jemds/2016/1129
Written Informed Consent was obtained from all 30 Nulliparous women admitted in the Labour room for Safe Institutional delivery from October 2015 to June 2016. $18 \mathrm{G}$ Epidural kit (System I), L A solution 2\% lignocaine in $2 \mathrm{~mL}$ syringe, Fentanyl and Ropivacaine ampoules, Multiparameter monitor, and Emergency kit.

\section{Position}

Sitting to avoid acute flexion as pressure of thighs on gravid uterus transiently reduces Uteroplacental blood flow.

Space

Lowest and widest space - L4-5.

\section{Approach}

Midline, slightly bevel facing cephalic direction.

Space confirmed by LORA (Loss of Resistance to Air) fixed the catheter without leaving any space between plaster and the catheter exit along the lordotic curvature at $12^{\text {th }}$ mark. Activation of Epidural Analgesia was done with $0.07 \%$ Ropivacaine (15-20 mL) and 30-50 $\mu \mathrm{g}$ Fentanyl given through the catheter at $3 \mathrm{~cm}$ dilatation of Cervix in sitting position, waited for 20 minutes.

The drug was administered in Intermittent bolus doses Assessed the motor block, Slow Leg Raising test, and Knee bend test.

\section{Modified Bromage Score}

1. Complete block, unable to move feet and knee.

2. Almost complete block, able to move feet.

3. Partial block just able to move knees.

4. Detectable weakness of Hip flexion.

5. No detectable weakness of Hip flexion. 
Patient with MBS score 5 were asked to stand or walk with the help of assistant or spouse under continuous vigilance. Patient is allowed to walk for 10-20 minutes in hour.

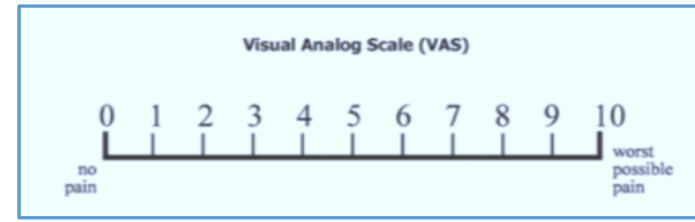

Level of Sensory Block was assessed with Visual Analogue Scale

\section{Inclusion Criteria}

1. Normal healthy, full term,

2. Singleton pregnancy,

3. Vertex presentation,

4. Active first stage of labour,

5. Age 18-30 yrs.,

6. Weight $<75 \mathrm{~kg}$,

7. Height $>5 \mathrm{ft}$. and,

8. ASA-II pregnant women (ASA I grade cannot be ascribed to Pregnant Women as all pregnant women come under ASA II in ASA Physical Status Classification System)

\section{Exclusion Criteria}

1. All complicating pregnancies with coexisting diseases.

2. Patient refusal and non-cooperative pregnant.

3. Local infections, frank coagulopathies.

4. Known allergic to LA, opioids, any other drugs.

\section{DISCUSSION}

The concept of pain relief during childbirth is a relatively recent one. Practice of labour analgesia was started with the use of Ether by James young Simson ${ }^{7}$ during childbirth (3 months after Morton's historical demonstrations on October 16 $6^{\text {th }}$ 1846). John Snow 1853 administered chloroform ${ }^{8}$ to queen Victoria for her $8^{\text {th }}$ childbirth (Prince Leopold).

Today, pain relief in labour is a standard practice and epidural analgesia is GOLD STANDARD. With the use of epidural technique, full sensory block without motor block, the mother can actively participate in childbirth and she enjoys the birth of baby with the warm feeling of baby's descent and first cry of baby.

Over all acceptance of epidural analgesia for labour is around $60 \%$ in major maternity centres in US and one third of pregnant women choose epidural in UK according to 20052006 statistics. In India, it is still lacking.

"The delivery of newborn into the arms of conscious and pain free mother is one of the most exciting and rewarding moments in medicine": MOIR.

Labour pain is equal to the pain of digit amputation. More than $90 \%$ of labouring mothers request for pain relief during labour. Labour pain effects all systems in the body. Anaesthesiologist should not deny analgesia if there is a request from labouring mother.

\section{Labour Pain affects almost all Systems in the Body}

1. Respiratory system: Severe pain $\rightarrow$ Hyperventilation ${ }^{9} \rightarrow$ Increased $\mathrm{O}_{2}$ Consumption $\rightarrow$ Decreased availability of $\mathrm{O}_{2}$ to the foetus.

2. Cardiovascular System: Severe Pain $\rightarrow$ Increased Catecholamines $^{10}(\alpha, \beta$ Adrenergic receptor stimulation $)$ $\rightarrow$ Increased $\mathrm{CO}$ and tachycardia. Exaggerates hypertensive response in PIH patients.

3. Increased stress response may cause acid base imbalance.

4. Painful traumatic labour may lead to postpartum stress disorders and psychological disturbances.

Provision of Pain Relief in Labour by Epidural Analgesia ${ }^{11}$ Result in

1. Blunting of hyper and hypoventilation and haemodynamic response.

2. Decreased maternal catecholamine concentration decreases $\alpha$ and $\beta$ Stimulation $\rightarrow$ Improved Uteroplacental perfusion $\rightarrow$ Improved Uterine activity $\rightarrow$ Shortens first stage of labour.

3. Beneficial in underlying cardiorespiratory problems and patients with intracranial vascular pathology.

Walking or Ambulation ${ }^{12}$ during labour: Upright position $\rightarrow$ Enhancement of pelvic dimensions $\rightarrow$ Reduces aortocaval compressions $\rightarrow$ Increases coordination of uterine contractions (Uterine contractions, frequency) $\rightarrow$ Facilitates foetal head decent and relaxes pelvic musculature $\rightarrow$ Less need for Oxytocin augmentation $\rightarrow$ Shortens first stage of labour $\rightarrow$ Greatest maternal comfort and satisfaction.

Finally reduces Instrumental and Caesarean delivery ${ }^{13}$ and improves obstetric outcome with improved APGAR score and high maternal satisfaction.

With the combination of novel ${ }^{14}$ synthetic opioids with low-dose local anaesthetics, we can achieve no motor, less sympathetic, and more sensory block or maximum motor function preservation with minimum sympathetic effect and no sensory activity is achieved in walking epidural analgesia.

\section{Ideal Labour Analgesic Technique should}

1. Reduce pain dramatically.

2. Should not interfere with the progress of labour.

3. Should not increase the incidence of Caesarean sections.

4. Should not cause adverse effects ${ }^{15}$ either on mother or on foetus.

5. Should produce highest maternal satisfaction.

6. Should be useful to all labouring mothers.

Gold Standard Technique that affectively fulfils all the above parameters, which effectively relieves both somatic and visceral pain is epidural analgesia (Walking Epidural). This is achieved by a mixture of low-dose Local anaesthetic and opioids. Ropivacaine 0.07 to $0.1 \%$ or bupivacaine 0.0625 to $0.125 \%$ with fentanyl $2 \mu \mathrm{g} / \mathrm{mL}$ of local anaesthetic solution.

\section{Administered either}

- Intermittent bolus.

- Patient controlled analgesia.

- Continuous infusion.

\section{Prerequisite for Performing Epidural Analgesia}

1. Informed written consent

- Discussed about various options of pain relief.

- Detailed explanation about procedure.

2. Equipment for resuscitation checked

- AMBU, Airway, ETT, suction catheter, Laryngoscope,

3. Drugs Difficult airway kit, circuit and oxygen source, etc.

- Vasopressors, emergency drug kit. 
4. Wedge to correct Pelvic tilt.

5. Foetal heart monitoring - foetoscope/Doppler/CTG.

6. Airway assessment/Back examination and PAC.

7. Hydration with RL and DNS with a good venous access.

8. Recent platelet count.

\section{Causes of Failed Pain Relief are}

1. Patient with full dilatation of cervix.

2. Full bladder.

3. Catheter not in Epidural place.

\section{Complications}

1. Blood tap - minimised by

- Experienced anaesthesiologist.

- Midline approach (less vascular).

- Do not thread the catheter beyond $4 \mathrm{~cm}$.

2. Broken/sheared epidural catheter (micro, metallic/glass particles in CSF).

3. Inadvertent Dural puncture, Dural tap, and PDPH.

4. Shivering - prevented by low-dose IV/epidural pethidine or fentanyl.

\section{RESULTS}

\begin{tabular}{|c|c|c|c|c|}
\hline $\begin{array}{l}\text { Sl. } \\
\text { No. }\end{array}$ & Parameter & Observation & $\begin{array}{l}\text { No. of } \\
\text { Cases }\end{array}$ & $\%$ \\
\hline \multirow[t]{2}{*}{1} & $\begin{array}{c}\text { Onset of } \\
\text { Analgesia }\end{array}$ & $5-10 \min$ & 20 & 66.67 \\
\hline & & $10-15 \mathrm{~min}$ & 10 & 33.33 \\
\hline \multirow[t]{3}{*}{2} & $\begin{array}{l}\text { Duration of } \\
\text { Analgesia }\end{array}$ & 80-99 min & 8 & 26.67 \\
\hline & & $100-119 \mathrm{~min}$ & 16 & 53.33 \\
\hline & & $120-140 \mathrm{~min}$ & 6 & 20.00 \\
\hline \multirow[t]{3}{*}{3} & $\begin{array}{l}\text { Quality of } \\
\text { Analgesia }\end{array}$ & 0 & 20 & 66.67 \\
\hline & (VAS) & 1 & 8 & 26.67 \\
\hline & & 2 & 2 & 6.66 \\
\hline 4 & $\begin{array}{l}\text { Motor Block } \\
\text { (MBS ) }\end{array}$ & 5 & 30 & 100 \\
\hline \multirow[t]{3}{*}{5} & $\begin{array}{l}\text { Mode of } \\
\text { Delivery }\end{array}$ & $\begin{array}{l}\text { Normal } \\
\text { vaginal }\end{array}$ & 26 & 86.67 \\
\hline & & Caesarean & 1 & 3.33 \\
\hline & & Forceps & 3 & 10 \\
\hline \multirow[t]{6}{*}{6} & $\begin{array}{c}\text { APGAR at } 1 \\
\text { min }\end{array}$ & 6 & 2 & 6.66 \\
\hline & & 7 & 0 & 0 \\
\hline & & 8 & 28 & 93.33 \\
\hline & $\begin{array}{c}\text { APGAR at } 5 \\
\text { min }\end{array}$ & 8 & 1 & 3.33 \\
\hline & & 9 & 1 & 3.33 \\
\hline & & 10 & 28 & 93.34 \\
\hline \multirow[t]{4}{*}{7} & $\begin{array}{c}\text { Duration of } \\
\text { First Stage of } \\
\text { Labour }\end{array}$ & $140-159 \mathrm{~min}$ & 4 & 13.33 \\
\hline & & $160-179 \mathrm{~min}$ & 11 & 36.67 \\
\hline & & $180-190 \mathrm{~min}$ & 12 & 40.0 \\
\hline & & $191-220 \mathrm{~min}$ & 3 & 10.0 \\
\hline
\end{tabular}

In the present study, the onset of analgesia was 10 minutes and lasted for 3 hours 30 minutes. There is no effect on the duration of $1^{\text {st }}$ stage of Labour. APGAR score at 1 minute was 8 in $94 \%$ cases and APGAR at 5 minutes was 10 in $94 \%$ of cases. The result of the present study was similar to the studies conducted by Alberts et $\mathrm{al}^{16}$ and Chestnut et al. ${ }^{17}$

\section{Legal Implications}

Legal claims are mainly due to - pain during procedure and labour; Emotional and Back pain.

Hence, all issues involving labour analgesia should be appropriately discussed with the patient, if possible video counseling maybe taken for evidence based analgesia. This is best done ${ }^{18}$ in the form of Patient education programme during their antenatal visits with the team work of gynaecologists.

\section{CONCLUSION}

Walking Epidural Analgesia can be best performed with minimal local anaesthetic volume and minimum local anaesthetic dose of $15 \mathrm{~mL}$ of $0.125 \%$ Ropivacaine with Fentanyl $2 \mu \mathrm{g} / \mathrm{mL}$. With this dose of Epidural adequate sensory block was obtained with maximum preservation of motor function. So that parturient participated actively in the process of childbirth without delay in first stage ${ }^{19}$ of labour. No significant haemodynamic changes and adverse effects were observed in both newborn and mother.

Gynaecologists, Anaesthesiologists, and nursing people work as a team and make the labouring mother to forget the pain and enjoy the birth of baby with full and active participation.

\section{REFERENCES}

1. Breen TW, Shapiro T, Glass B, et al. Epidural anaesthesia for labour in an ambulatory patient. Anaesth Analg 1993;77(5):919-24.

2. Boulier V, Gomis P, Lautner C, et al. Minimal concentration of ropivacaine and levobupivacaine with sufentanil for epidural analgesia in labour. Internl J Obstet Anaesth 2009;18(3):226-30.

3. Lacassie HJ, Habib AS, Lacassie HP, et al. Motor blocking minimum local anaesthetic concentrations of bupivacaine, levobupivacaine, and ropivacaine in labour. Reg Anaesth Pain Med 2007;32(4):323-9.

4. Leighton BL, Halpern SH. The effect of epidural analgesia on labour, maternal and neonatal outcomes: a systematic review. Am J Obstec Gynaecol 2002;186(5 Suppl Nature):S69-77.

5. Atienzar MC, Palanca JM, Torres F, et al. A randomised comparison of levobupivacaine, bupivacaine and ropivacaine with fentanyl, for labour analgesia. Int J Obstet Anaesth 2008;17(2):106-11.

6. Bloom SL, McIntire DD, Kelly MA, et al. Lack of effect of walking on labour and delivery. $\mathrm{N}$ Engl $\mathrm{J}$ Med 1998;339(2):76-9.

7. Cohen J, Simpson JY, De Sola RA. Genesis: Chapter 3, verse 16. Obstet Gynaecol 1996;88:895-8.

8. Snow J. On administration of chloroform in during parturition. Assoc Med J 1853;1(23):500-2.

9. Miller FC, Petric RH, Arce JJ, et al. Hyperventilation during labour. Am J Obstec Gynaecol 1974;120(4):48995.

10. Lederman RP, Lederman E, Work B, et al. Anxiety and epinephrine in multiparous women in labour: relationship to duration of labour and foetal heart rate pattern. Am J Obstet Gynaecol 1985;153(8):870-7. 
11. Hawkins JL. Epidural analgesia for labour and delivery. $\mathrm{N}$ Engl J Med 2010;362:1503-10.

12. Comparative obstetric mobile epidural trial study group UK. Effect of low-dose mobile versus traditional epidural technique on mode of delivery: a randomised controlled trial. Lancet 2001;358(9275):19-23.

13. Wong CA, Scavone BM, Peaceman AM, et al. The risk of caesarean delivery in neuraxial analgesia given early vs. late in labour. N Engl J Med 2005;352(7):655-65.

14. Macarthur AJ. Gerard W. Ostheimer what's new in obstetric anaesthesia lecture. Anaesthesiology 2008;108(5):777-85.

15. Lieberman E, O'donoghue C. Unintended effects of epidural analgesia during labour: a systematic review. Am J Obstec Gynaecol 2002;186(5 Suppl Nature):S31-68.
16. Albers LL, Anderson D, Cragin L, et al. The relationship of ambulation in labour to operative delivery. J Nurse Midwifery 1997;42(1):4-8.

17. Chestnut DH, Vandewalker GE, Owen CL, et al. The influence of continuous epidural bupivacaine analgesia on second stage of labour and method of delivery in nulliparous women. Anaesthesiology 1987;66(6):77480.

18. Leo S, Sia AT. Maintaining labour epidural analgesia: what is the best option? Curr Opin Anaesthesiol 2008;21(3):263-9.

19. Brancato RM, Church S, Stone PW. A meta-analysis of passive descent versus immediate pushing in nulliparous women with epidural analgesia in the second stage of labour. J Obstet Gynaecol Neonatal Nurs 2008;37(1): 4-12. 